BLS 32, No 1 2006. DOI: http://dx.doi.org/10.3765/bls.v32i1.3457 (published by the Berkeley Linguistics Society and the Linguistic Society of America)

\title{
Light Verb Voicing and Japanese Phonological Lexicon
}

\author{
KAZUTAKA KURISU \\ Kobe College
}

\section{Introduction}

Postnasal voicing is one of the rich voicing phenomena in modern Japanese. It has received extensive attention in a variety of earlier literature, but still understudied is its effect in the light verb construction. The Japanese light verb /suru/ often follows Sino-Japanese items historically borrowed from Chinese. In this paper, I investigate postnasal voicing in the light verb construction and consider its theoretical implications for the phonological organization of Japanese grammar.

An interesting observation is that postnasal voicing in the light verb construction is not merely a matter of all or nothing. Data comprising a Sino-Japanese stem and the light verb reveal that postnasal voicing occurs when it is expected (i.e., after a nasal) and that it is blocked when it should not take place (i.e., after a non-nasal). However, there are abundant cases where postnasal voicing is blocked when it is predicted to occur and those where the initial consonant of the light verb is subject to voicing in the absence of a preceding nasal. Embedding this finding in the core-periphery model (Itô and Mester 1995a, 1995b, 1999, 2003), I claim that some examples behave like native Yamato items phonologically while others exhibit behavior like Sino-Japanese items.

I also argue that the non-uniform behavior of light verb voicing leads to two further theoretically important conclusions regarding the morphology-phonology interface. First, the phono-lexical organization does not necessarily accord with morphological headedness. Second, Japanese phonological lexicon is independent of etymology. These two conclusions are not new. My discussion rather provides independent support for relevant earlier literature.

In addition, two intriguing puzzles exist. First, postnasal voicing is consistently prevented when a Sino-Japanese noun precedes the light verb. Second, postnasal voicing takes place persistently when a native Yamato item is followed by the light verb. There is literally no exception in these environments. In this sense, these two cases are demonstrably different from morphological complexes consisting of a Sino-Japanese stem and the light verb. In order to account for these two cases, I discuss that distinctions of mono/bi-morphemic structures and lexical/postlexical processes need to be taken into consideration. 
Kazutaka Kurisu

This paper is organized as follows. Section 1 discusses how the non-uniform pattern of morphological complexes comprising a Sino-Japanese stem and the light verb are to be understood, framing the analysis in Optimality Theory (OT; Prince and Smolensky 2004). In section 2, I examine cases where the light verb follows a Sino-Japanese noun. As stated above, postnasal voicing is consistently blocked in this context. I argue that such examples involve word formation at the postlexical level. The logic of the argument is then that postlexical complexes are not sensitive to lexical postnasal voicing. Section 3 turns to examples with persistent postnasal voicing. I claim that such examples are mono-morphemic although they seem to involve the light verb. Finally, this paper is concluded in section 4.

\section{Sino-Japanese Stems and Light Verb}

This section discusses postnasal voicing attested in morphological complexes of a Sino-Japanese stem (henceforth, SJS) and the light verb. It is beneficial to present some preliminary information regarding the morphological and phonological nature of SJSs before going into the main issue.

A single Chinese character corresponds to one SJS. As illustrated in (1), it is monosyllabic or disyllabic (Itô and Mester 1996, Kurisu 2000). SJSs are usually bound except for a limited number of SJSs (e.g., [gaku] 'learning'). The minimal word unit in Sino-Japanese is canonically a stem compound, as exemplified in (2).

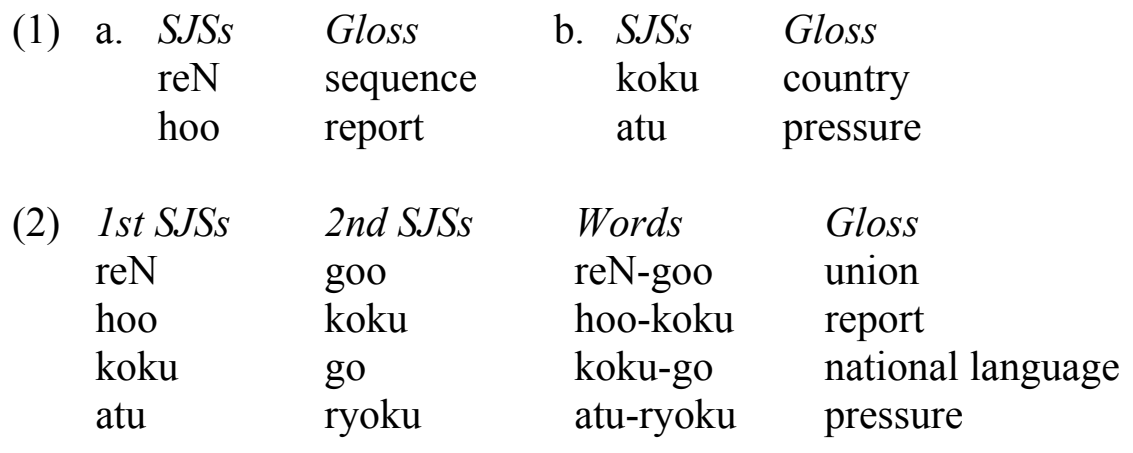

Equipped with the background above, let us look at (3), where each example consists of a SJS and the light verb. Comparing examples as in (3a) and (3d), Rice (2005) maintains that postnasal voicing takes effect in the light verb construction. She correctly argues that initial voicing of the light verb is not sequential voicing productively observed in nominal compounds since voicing would equally occur in (3a) as well otherwise. But there are many examples as in (3b) and (3c). In (3b), the initial consonant of the light verb is voiced despite the fact that the light verb is preceded by a vowel. By contrast, postnasal voicing simply does not occur in (3c). Rice rather disregards them, but similar examples are too many to be ignored. In addition, notice that minimal pairs exist in terms of voicing (i.e., [koosuru] 'resist' vs. [koo-zuru] 'give a lecture', and [saN-suru] 'calculate' vs. [saN- 


\section{Light Verb Voicing}

zuru] 'visit'). This observation suggests that all the four types of examples in (3) call for an analysis as non-exceptional data.

(3)

$\begin{array}{ll}\text { a. } & \text { SJS+suru forms } \\ & \text { kai-suru } \\ \text { hai-suru } & \text { soo-suru } \\ \text { tai-suru } \\ \text { koo-suru } \\ \\ \text { c. } & \text { SJS+suru forms } \\ & \text { haN-suru } \\ & \text { saN-suru } \\ & \text { meN-suru } \\ \text { hiN-suru } & \text { seN-suru }\end{array}$

Gloss
meet
distribute
write
oppose
resist
Gloss
oppose
calculate
face
become poor
declare

b. SJS+suru forms

mee-zuru

too-zuru

syoo-zuru

hoo-zuru

koo-zuru

Gloss

command

throw

give rise to

report

give a lecture
d. SJS+suru forms Gloss daN-zuru assert beN-zuru speak geN-zuru reduce neN-zuru pray saN-zuru visit

Postnasal voicing is not pervasive, but the relevant constraint is demonstrably *NC (Pater 1999). This is a markedness constraint militating against a sequence of a nasal and a voiceless obstruent.

As exemplified in (4a), NC clusters are not allowed in Yamato-Japanese, the native vocabulary. This inhibition is attested in productive alternations as well. As illustrated in (4b), a voiceless obstruent after a nasal undergoes voicing across a morpheme boundary in verbal inflectional morphology.
a. Yamato
Gloss
toNbo
dragonfly
uNzari
disgusted
syoNbori depressed
b. Yamato
Gloss
$/$ sin-ta/ $\rightarrow$ [siN-da]
die (past)
$/$ sin-te $/ \rightarrow[$ siN-de $]$
die (gerundive)
$/$ sin-tara $/ \rightarrow[$ siN-dara $]$
die (subjunctive)

On the other hand, Sino-Japanese items breach the *NC constraint, as in (5a). There are many items as in (5b), but voiced obstruents after a nasal are not due to postnasal voicing. Rather, they are underlying.

\begin{tabular}{|c|c|c|c|}
\hline Sino & Gloss & b. Sino & Gloss \\
\hline siN-po & progress & iN-boo & plot \\
\hline seN-taku & choice & kaN-daN & quiet conversation \\
\hline reN-kee & connection & seN-geN & declaration \\
\hline kaN-satu & observation & kaN-zeN & perfection \\
\hline
\end{tabular}

In OT terms, the contrast between (4) and (5) can be captured by the ranking in (6) (Itô and Mester 1995a, 1995b, 1999, 2003). Ident-[voi] crucially outranks *NC in Sino-Japanese, so NC o clusters are ruled in. By contrast, Yamato-specific 


\section{Kazutaka Kurisu}

Ident-[voi] is dominated by $* \mathrm{NC}$, so they are banned in the native vocabulary. Faithfulness relativization captures distinct behavior of the two lexical classes.

(6) Ident-[voi] $]_{\text {Sino }} » * \mathrm{NC}$ » $»$ Ident-[voi] $]_{\text {Yamato }}$

Now, the question is how the examples in (3) are incorporated in (6). (3c) and (3d) are straightforward. They disobey and respect the *NC constraint, respectively. This indicates that (3c) is categorized with Sino-Japanese items whereas (3d) is grouped with Yamato-Japanese items.

By contrast, SJSs in (3a) and ( $3 b$ ) do not end in a nasal, so postnasal voicing is of no help for placing them in the constraint hierarchy in (6). To the best of my knowledge, no empirical evidence makes clear whether they are to be classified into Yamato-Japanese or Sino-Japanese. Assuming that markedness constraints are initially all ranked over faithfulness constraints (Smolensky 1996, Davidson et al. 2004), maximally unmarked structure is preferred. In the absence of evidence to the contrary, (3a) and (3b) are reasonably grouped with Yamato-Japanese items.

In summary, the four types of data in (3) can be captured by the constraint ranking in (7). ${ }^{1}$

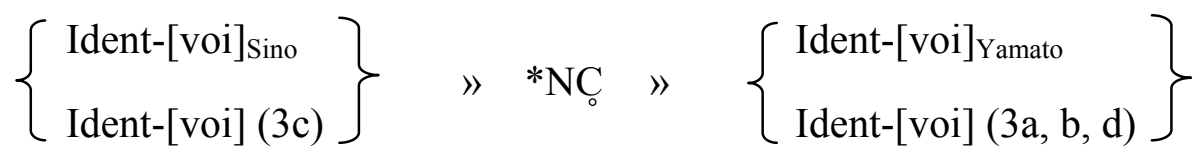

The discussion so far has two significant corollaries. First, the phono-lexical structure does not always reflect morphological headedness. The morphological complexes in (3) comprise a SJS and the light verb. Their grammatical category is a verb, so the light verb serves as the head. The light verb is undoubtedly affiliated with Yamato-Japanese, but (3c) exhibits behavior parallel to Sino-Japanese.

Second, the Japanese phonological lexicon is independent of etymology, as discussed by Fukazawa et al. (1998), Itô and Mester (1999, 2003), Tateishi (2003), and Fukazawa and Kitahara (2005). This is evident since the forms in (3) consist of two morphemes belonging to two different lexical classes. Independence of the Japanese phonological lexicon and etymology is further demonstrated in (8) (Itô and Mester 2003:150). Sequential voicing (or rendaku) applies to

\footnotetext{
${ }^{1}$ As pointed out by Jaye Padgett, this analysis implies that the initial consonant of the light verb is underlyingly voiced in (3b). This may appear to suggest that one promising move is to adopt the idea of allomorph selection, where all allomorphs are listed in the input and particular choice of the best one depends on a given constraint ranking (Tranel 1998). But there is an obvious problem with this approach that it does not work for (3c) and (3d). By hypothesis, no faithfulness violation is incurred irrespective of which allomorph is chosen, so Ident-[voi] has no room to play a role. Given *NC, it is wrongly predicted that the forms in (3c) and (3d) converge on the voiced variant of the light verb, so the notion of allomorph selection is not easily applicable for the case at hand. But the assumption that the initial consonant of the light verb is voiced in (3b) is admittedly less than satisfactory. I leave this issue open for future research.
} 


\section{Light Verb Voicing}

Yamato items (Martin 1952:48). In (8), the second compound members are SinoJapanese items etymology-wise, but they still undergo sequential voicing. As cogently argued by Takayama (1999) and Itô and Mester (2003), the SinoJapanese words in (8) are presumably nativized in contemporary Japanese, showing that phonology is not necessarily in tandem with etymology (see also Vance 1996). The forms in (8) in turn provide independent support for my claim here.

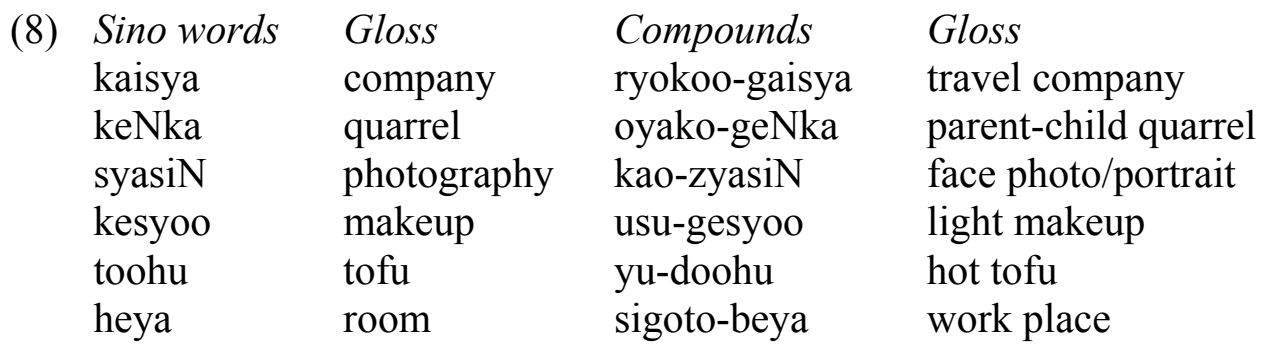

\section{Puzzle I: Robust Resistance to Voicing}

The data presented in section 1 suggest that light verb voicing does not display a uniform pattern. Two interesting puzzles exist with respect to applicability of light verb voicing. One is seen in cases where the initial consonant of the light verb is never voiced, and the other is those where it is consistently voiced. I discuss these two cases in turn in this section and in section 3, respectively.

Consider the examples in (9), where the light verb does not undergo voicing regardless of the segment immediately before the light verb. As illustrated in (9b), therefore, postnasal voicing is also prevented.

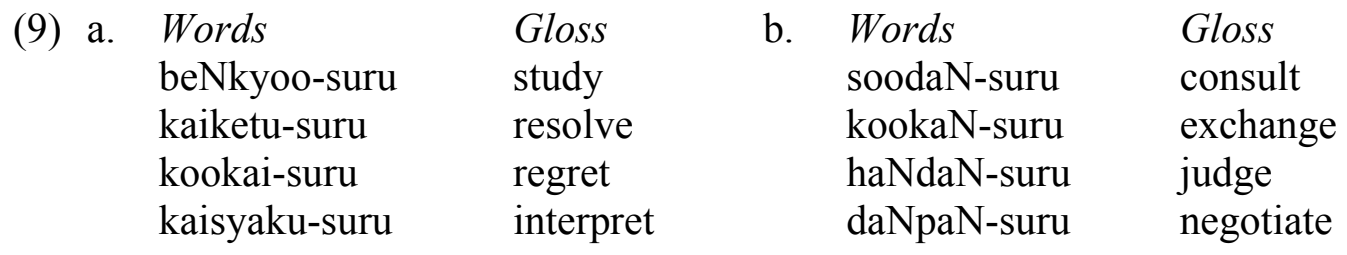

The immediate question is why voicing is always blocked in these examples, even after a nasal. The key observation is that a bound stem precedes the light verb in (3) while the light verb follows a Sino-Japanese noun (henceforth, SJN) in (9). The elements before the light verb can stand as independent words in (9).

Building on this observation, I propose that the morphological complexes in (3) are lexical whereas those in (9) are constructed at the postlexical level. There is some evidence to support this proposal. A first indication is drawn from their behavior in accentuation. As shown in (10a), mono-morphemic native verbs are unaccented or attract the accent to the penultimate syllable. Verbal compounds follow the same pattern, as exemplified in (10b) (Akinaga 1985). 
Kazutaka Kurisu

\begin{tabular}{|c|c|c|c|c|}
\hline (10) a. & $\begin{array}{l}\text { Unaccented verbs } \\
\text { neru } \\
\text { agaru } \\
\text { marumeru }\end{array}$ & $\begin{array}{l}\text { Gloss } \\
\text { sleep } \\
\text { go up } \\
\text { round }\end{array}$ & $\begin{array}{l}\text { Accented verbs } \\
\text { kúru } \\
\text { sagáru } \\
\text { tabanéru }\end{array}$ & $\begin{array}{l}\text { Gloss } \\
\text { come } \\
\text { go down } \\
\text { bundle }\end{array}$ \\
\hline b. & $\begin{array}{l}\text { Unaccented compounds } \\
\text { mi-ageru } \\
\text { kake-yoru } \\
\text { de-kakeru }\end{array}$ & $\begin{array}{l}\text { Gloss } \\
\text { look up } \\
\text { run up to } \\
\text { go out }\end{array}$ & $\begin{array}{l}\text { Accented compounds } \\
\text { ne-naósu } \\
\text { hare-agáru } \\
\text { osi-nokéru }\end{array}$ & $\begin{array}{l}\text { Gloss } \\
\text { sleep again } \\
\text { swell up } \\
\text { push away }\end{array}$ \\
\hline
\end{tabular}

Crucial examples are given in (11). As in (11a), the morphological complexes in (3) exhibit exactly the same pattern as (10). ${ }^{2}$ The forms in (11b) also can be either unaccented or accented. But their accentuation is different from (10) and (11a). The accent does not fall on the penultimate syllable in (11b). As described by McCawley (1968:144), the examples (11b) retain the accent pattern of SJNs that the light verb is attached to. [beNkyoo] 'study' and [soodaN] 'consultation' are accentless, but [kóokai] 'regret' and [háNdaN] 'judgment' are accented.

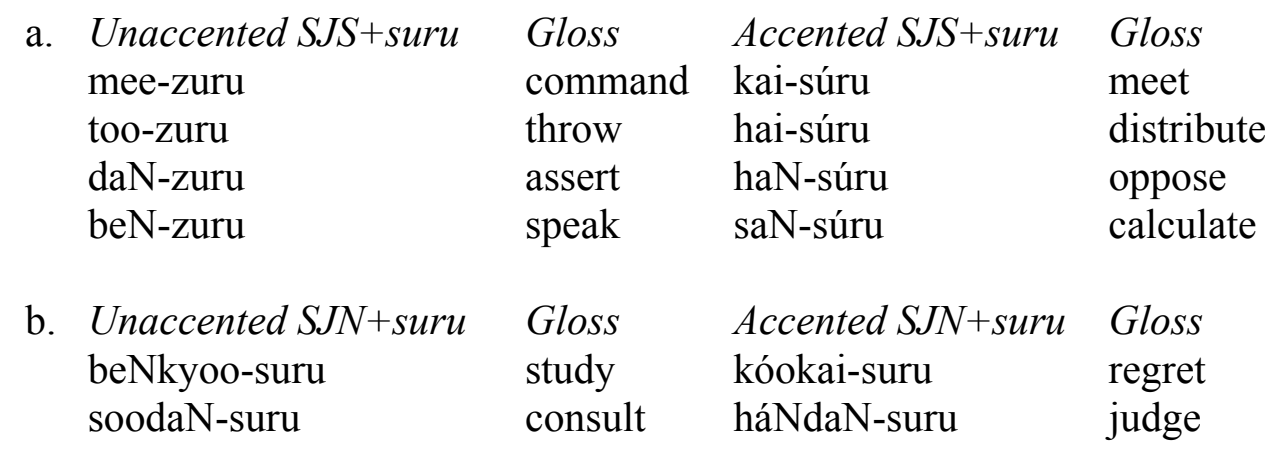

This observation strongly indicates that the examples in (3) are lexical words, but those in (9) are not. McCawley (1968:144) informally states that there is some junctural element between a SJN and the light verb. As I discuss shortly below, my analysis lends support to his intuitive remark.

Because the forms in (9) are not lexical, they are likely to involve postlexical word formation. This is confirmed by positive evidence. Compelling phonological evidence comes from adverbial reduplication. As demonstrated in (12a), a whole base undergoes copying when it is bimoraic or larger. But total reduplication of a subminimal base is accompanied by vowel lengthening, as shown in (12b). This

\footnotetext{
${ }^{2}$ Light verb voicing and accentedness are in complementary distribution for (3). Given that the voicing phenomenon is surface realization of a linking morpheme (Itô and Mester 1986, 2003) and that the forms in (11a) conform to the accent pattern of lexical verbal compounds, this complementary distribution makes sense. The question is why voicing and an accent cooccurr in nominal compounds (e.g., /nise-sakura/ $\rightarrow$ [nise-zákura] 'fake cherry'). This is maybe attributed to different degrees of compounding. Nominal compounds are more tightly connected than the forms in (3).
} 


\section{Light Verb Voicing}

reflects word minimality in Japanese (Poser 1990, Itô 1990, Kurisu 2005). (12c) shows that compounds also undergo total reduplication, just like simple verbs.

$\begin{array}{lll}\text { Adverbial forms } & \text { Reduplication forms } & \text { Gloss } \\ \text { tabe-tabe } & \text { eat } \\ \text { hasiri } & \text { hasiri-hasiri } & \text { run } \\ \text { b. } \text { si } & \text { sii-sii } & \text { do } \\ \text { mi } & \text { mii-mii } & \text { see } \\ \text { c. naki-dasi } & \text { nakidasi-nakidasi } & \text { start crying } \\ \text { tobi-hane } & \text { tobihane-tobihane } & \text { jump } \\ \text { kaki-maze } & \text { kakimaze-kakimaze } & \text { stir up }\end{array}$

Reduplication patterns of (3) and (9) are exemplified in (13). As in (13a), the morphological complexes in (3) take the same pattern as simple and compounded verbs. But in (9), only the light verb undergoes reduplication, as shown in (13b). Moreover, the vowel of the light verb undergoes prosodic augmentation. Comparison of (12c) and (13b) reveals that the forms in (9) are not compounds either.

$\begin{array}{lll}\text { Adverbial forms } & \begin{array}{l}\text { Reduplication forms } \\ \text { kaisi-kaisi }\end{array} & \begin{array}{l}\text { Gloss } \\ \text { meet }\end{array} \\ \text { a. } & \text { kai-si } & \text { oppose } \\ \text { haN-si } & \text { meezi-haNsi } & \text { command } \\ \text { mee-zi } & \text { daNzi-daNzi } & \text { assert } \\ \text { daN-zi } & \text { beNkyoo-sii-sii } & \text { study } \\ \text { b. beNkyoo-si } & \text { kookai-sii-sii } & \text { regret } \\ \text { kookai-si } & \text { soodaN-sii-sii } & \text { consult } \\ \text { soodaN-si } & \text { haNdaN-sii-sii } & \text { judge } \\ \text { haNdaN-si } & \end{array}$

The difference between (13a) and (13b) makes immediate sense if the forms in (9) are constructed at the postlexical level (Kageyama 1976-7, Kurisu 2001). My proposal is schematically depicted in (14). First, the light verb and preceding SJN are segregated at the lexical level when adverbial reduplication applies. As shown in (14a), therefore, only the light verb is targeted by total reduplication. /si/ is less than bimoraic, so vowel lengthening occurs. The output of reduplication is supplied to the deep structure, and it is base-generated under the V node. A SJN occupies the complement position, as in (14b). The SJN is subsequently incorporated into the light verb (Barker 1988), yielding the surface representation in $(14 \mathrm{c})$. 
Kazutaka Kurisu

(14)

a. Reduplication $/$ si $/ \rightarrow[$ sii-sii $]$ b. Deep structure

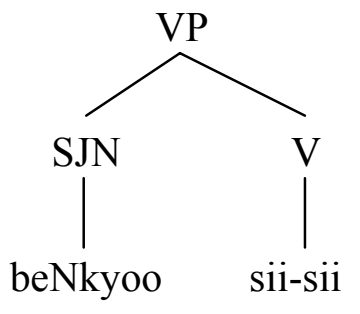

c. Surface structure

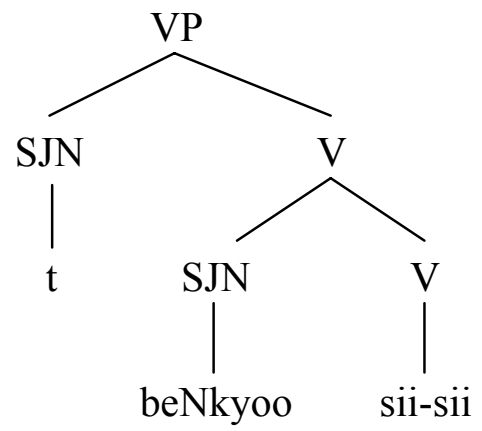

Based upon the observation that SJNs behave syntactically either as verbs or nouns, Kurisu (2001) argues that the position of SJN is a verb when incorporation takes place. This syntactic incorporation can be then motivated by complementation of semantic and tense requirements imposed on verbs. SJNs are semantically rich with substantial meanings. But they cannot be inflected for tense. By contrast, the light verb has a poor meaning, but it is inflected for tense. Combination of the two syntactic verbs through incorporation yields a full-fledged verb.

Summarizing the discussion so far, the examples in (3) are lexical complexes whereas those in (9) are postlexical complexes. This analysis explains two facts. First, no voicing takes place in (9) because the voicing process is lexical. Second, the reason why (9) exhibits different behavior from lexical and compounded verbs becomes clear with my analysis, where (9) involves postlexical word formation. In a nutshell, postlexical word formation is insensitive to phonological processes occurring at the lexical level.

\section{Puzzle II: Persistent Application of Voicing}

The second puzzle is the fact that there are examples with consistent voicing, the opposite situation of (9). Relevant examples are provided in (15).

$\begin{array}{llll}\text { zuru forms } & \text { Gloss } & \text { zuru forms } & \text { Gloss } \\ \text { karoNzuru } & \text { think little of } & \text { sakiNzuru } & \text { go ahead } \\ \text { omoNzuru } & \text { honor/respect } & \text { amaNzuru } & \text { put up with } \\ \text { utoNzuru } & \text { neglect } & \text { soraNzuru } & \text { recite from memory }\end{array}$

There are two important generalizations. First, it seems that these examples appear to contain the light verb and that its initial consonant seems to be voiced. Second, the segment immediately preceding the voiced consonant is consistently a nasal. Therefore, it seems that what is going on in (15) is postnasal voicing. In effect, I argue that it is actually postnasal voicing. However, caution is necessary. We already saw in (3) that postnasal voicing is not exceptionless. The question to be addressed is why postnasal voicing takes place in (15) with no exception. 


\section{Light Verb Voicing}

My key proposal is that the examples in (15) are mono-morphemic items, as represented in (16). This proposal is tantamount to saying that the apparent light verb is indeed not an independent morpheme, unlike in (3) and (9).

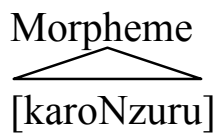

Several pieces of evidence indicate that the mono-morphemic representation in (16) is correct. First, the phonological strings preceding [zuru] (e.g., [karoN]) can neither stand as independent words nor cooccur with any other morphemes. In this sense, they are highly bound.

In many cases, the elements before [zuru] are semantically associated with native adjectives, as demonstrated in (17). One might bring up the possibility of deadjectival derivation. But this is turned down for two reasons. First, there is no coherent way to generalize the phonological operation of deadjectivization. The vowel right before $[\mathrm{N}]$ in each verb is not always the same as the corresponding vowel in adjectives. It is not a fixed vowel either. Second, not all forms in (15) have a semantically related adjective (e.g., [soraNzuru]), so the deadjectival derivation cannot cover all examples given in (15). These two problems significantly degrade the validity of deadjectivization.

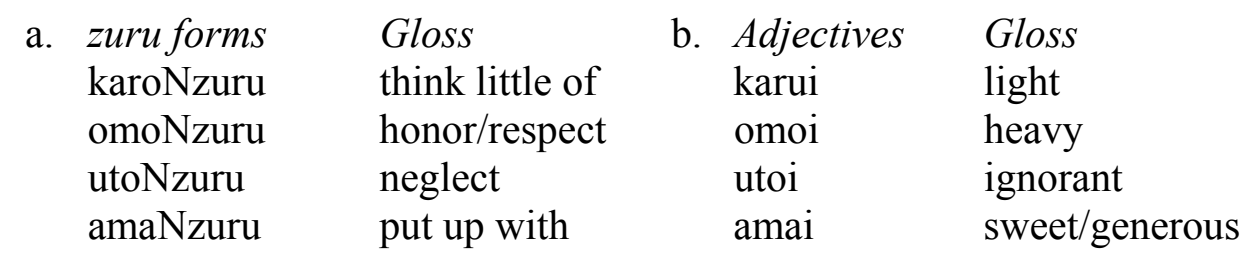

More evidence for the representation in (16) comes from adverbial reduplication. As illustrated in (18), reduplication creates total reduplication. This is the same pattern as (12) and (13a). As I already discussed, this pattern of reduplication indicates that the base of reduplication is formed at the lexical level. At the minimum, (18) shows that the examples in (15) do not involve any postlexical word formation. This in turn suggests that the mono-morphemic structure in (16) is not incorrect.

(18)

Adverbial forms
karoNzi
omoNzi
utoNzi
sakiNzi
amaNzi
soraNzi

Reduplication forms
karoNzi-karoNzi
omoNzi-omoNzi
utoNzi-utoNzi
sakiNzi-sakiNzi
amaNzi-amaNzi
soraNzi-soraNzi

Gloss

think little of

honor/respect

neglect

go ahead

put up with

recite from memory 


\section{Kazutaka Kurisu}

Finally, all the examples in (15) contain only one voiced obstruent. No more than one voiced obstruent is permitted per morpheme in native Yamato-Japanese. This is an OCP effect known as Lyman's Law (Martin 1952, McCawley 1968, Itô and Mester 1986, 2003, Vance 1987). The fact that the forms in (15) respect this phonological restriction is suggestive of the correctness of my proposal that they are affiliated with Yamato-Japanese.

Note that Lyman's Law is entirely immaterial in (3). For example, the first example in (3d) (i.e., [daN-zuru] 'assert') contains two voiced obstruents (i.e., [d] and $[\mathrm{z}]$ ). As I argued in section 1, the examples in (3) are bi-morphemic. This means that the pertinent voiced obstruents are separated into distinct morphemes. As a result, Lyman's Law is impeccably satisfied by the forms in (3d) although they behave like Yamato-Japanese items (see (7)).

Summing up this section, accentuation and adverbial reduplication reveal that the entire forms in (15) do not involve any postlexical word formation. But they are clearly different from (3) with respect to Lyman's Law. This is accounted for by positing the mono-morphemic structure depicted in (16). This morphological factor differentiates (15) from (3) and (9).

Returning to the initial question posed at the beginning of this section, the present analysis offers a straightforward account for why [zuru] always appears in (15). All the examples in (15) behave like morphologically simple native verbs, so *NC must be satisfied, given the ranking in (6).

\section{Conclusion}

This paper dealt with a rather comprehensive range of data surrounding voicing of the light verb. I demonstrated that the attested three-way pattern is attributed to lexical/postlexical and mono/bi-morphemic distinctions. The finding obtained in this study is summarized in the table in (19).

\begin{tabular}{|c|c|c|c|}
\cline { 2 - 4 } \multicolumn{1}{c|}{} & $\begin{array}{c}\text { Morphological } \\
\text { structure }\end{array}$ & $\begin{array}{c}\text { Level of } \\
\text { word formation }\end{array}$ & $\begin{array}{c}\text { Lexical } \\
\text { class }\end{array}$ \\
\hline$(3 \mathrm{a}, 3 \mathrm{~b}, 3 \mathrm{~d})$ & complex & lexical & Yamato \\
\hline$(3 \mathrm{c})$ & complex & lexical & Sino \\
\hline$(9)$ & complex & postlexical & Sino \\
\hline$(15)$ & simplex & lexical & Yamato \\
\hline
\end{tabular}

This table also makes clear that the examples discussed above are classified with either Yamato-Japanese or Sino-Japanese items. This observation is captured by the ranking in (20). With the disparate rankings of faithfulness constraints with respect to $* \mathrm{NC}$, it follows that the phono-lexical classification of a given item is not contingent upon morphological headedness or etymology. 


\section{Light Verb Voicing}

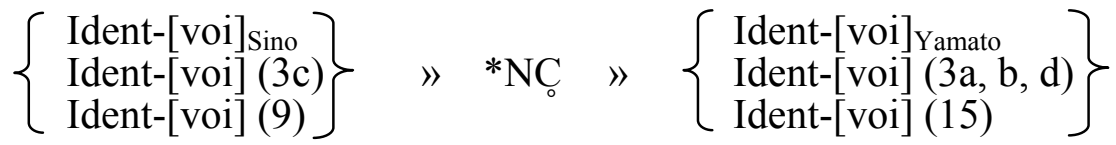

The examples in (9) are produced postlexically, so it automatically follows that lexical voicing does not occur. One may suppose that Ident-[voi](9) may be omitted from (20). But explicit inclusion of Ident-[voi](9) illuminates one important fact. Exploring opacity in German, Itô and Mester (2001) argue for the need of different rankings for lexical and postlexical components. Most importantly, the lexical level is less marked than the postlexical level. This elucidates the effect of structure preservation. The ranking of Ident-[voi](9) "* ${ }^{N C}$ can be seen along this line. The forms as in (3) and (15) are lexical, and their phonological markedness differs depending upon the stratum that they belong to. The forms in (9) are postlexical, so structure preservation is turned off. As a result, phonologically marked structure appears. This conjecture is evinced in much earlier literature, but correlations between phonological markedness and lexical/postlexical processes deserve more intensive and extensive scrutiny in the OT enterprise.

\section{Acknowledgements}

This paper benefited from discussion with the audiences at the annual BLS 32 meeting (February 10, 2006) as well as the participants in the Phonology Reading Group at the University of California, Santa Cruz (February 13, 2006). For many invaluable questions and comments on these occasions, I thank Larry Hyman, Junko Itô, Armin Mester, Jaye Padgett, and Natsuko Tsujimura. I am responsible for any remaining errors and infelicities.

\section{References}

Akinaga, Kazue. 1985. Kyootsuugo no Akusento [Accent of Standard Japanese]. In NHK, ed., Nihongo Hatsuon Akusento Ziten [Dictionary of Japanese Pronunciation and Accent]. 70-116 (Appendix).

Barker, Mark. 1988. Incorporation: A Theory of Grammatical Function Changing. Chicago: Chicago University Press.

Davidson, Lisa, Peter Jusczyk, and Paul Smolensky. 2004. The Initial and Final States: Theoretical Implications and Experimental Explorations of Richness of the Base. In R. Kager, J. Pater, and W. Zonneveld, eds., Constraints in Phonological Acquisition, 321-368. Cambridge: Cambridge University Press.

Fukazawa, Haruka, Mafuyu Kitahara, and Mitsuhiko Ota. 1998. Lexical Stratification and Ranking Invariance in Constraint-Based Grammars. Proceedings of the Chicago Linguistic Society 34(2):47-62.

Fukazawa, Haruka, and Mafuyu Kitahara. 2005. Ranking Paradoxes in Consonant Voicing in Japanese. In J. van de Weijer, K. Nanjo, and T. Nishihara, eds., Voicing in Japanese, 105-121. Berlin and New York: Mouton de Gruyter. 
Kazutaka Kurisu

Itô, Junko. 1990. Prosodic Minimality in Japanese. Proceedings of the Chicago Linguistic Society 26(2):213-239.

Itô, Junko, and Armin Mester. 1986. The Phonology of Voicing in Japanese: Theoretical Consequences for Morphological Accessibility. Linguistic Inquiry $17(1): 49-73$.

Itô, Junko, and Armin Mester. 1995a. Japanese Phonology. In J. Goldsmith, ed., The Handbook of Phonological Theory, 817-838. Cambridge, Massachusetts, Blackwell Publishers.

Itô, Junko, and Armin Mester. 1995b. The Core-Periphery Structure of the Lexicon and Constraints on Reranking. In J. Beckman, L. Walsh, and S. Urbanczyk, eds., University of Massachusetts Occasional Papers in Linguistics 18: Papers in Optimality Theory, 181-209.

Itô, Junko, and Armin Mester. 1996. Stem and Word in Sino-Japanese. In T. Otake and A. Cutler, eds., Phonological Structure and Language Processing: Cross-Linguistic Studies, 13-44. Berlin and New York: Mouton de Gruyter.

Itô, Junko, and Armin Mester. 1999. The Phonological Lexicon. In N. Tsujimura, ed., The Handbook of Japanese Linguistics, 62-100. Cambridge, Massachusetts: Blackwell Publishers.

Itô, Junko, and Armin Mester. 2001. Structure Preservation and Stratal Opacity in German. In L. Lombardi, ed., Segmental Phonology in Optimality Theory, 261-295. Cambridge: Cambridge University Press.

Itô, Junko, and Armin Mester. 2003. Japanese Morphophonemics: Markedness and Word Structure. Cambridge, Massachusetts: The MIT Press.

Kageyama, Taro. 1976-7. Incorporation and Sino-Japanese Verbs. Papers in Japanese Linguistics 5:117-155.

Kurisu, Kazutaka. 2000. Richness of the Base and Root-Fusion in Sino-Japanese. Journal of East Asian Linguistics 9(2):147-185.

Kurisu, Kazutaka. 2001. Case Marking and Incorporation in Sino-Japanese. Proceedings of the Chicago Linguistic Society 37(1):363-377.

Kurisu, Kazutaka. 2005. Gradient Prosody in Japanese. Journal of East Asian Linguistics 14(3):175-226.

Martin, Samuel. 1952. Morphophonemics of Standard Colloquial Japanese. Supplement to Language. Dissertation No. 47. Baltimore, Maryland: Linguistic Society of America.

McCawley, James. 1968. The Phonological Component of a Grammar of Japanese. The Hague: Mouton.

Pater, Joe. 1999. Austronesian Nasal Substitution and Other *NC Effects. In R. Kager, H. van der Hulst, and W. Zonneveld, eds., The Prosody-Morphology Interface, 310-343. Cambridge: Cambridge University Press.

Poser, William. 1990. Evidence for Foot Structure in Japanese. Language 66(1):78-105.

Prince, Alan, and Paul Smolensky. 2004. Optimality Theory: Constraint Interaction in Generative Grammar. Malden, Massachusetts: Blackwell. 


\section{Light Verb Voicing}

Rice, Keren. 2005. Sequential Voicing, Postnasal Voicing, and Lyman's Law Revisited. In J. van de Weijer, K. Nanjo, and T. Nishihara, eds., Voicing in Japanese, 25-45. Berlin and New York: Mouton de Gruyter.

Smolensky, Paul. 1996. The Initial State and 'Richness of the Base' in Optimality Theory. Technical Report. JHU-Cogsci-96-4. John Hopkins University.

Takayama, Tomoaki. 1999. Syakuyoogo no Rendaku/Kooonka ni tsuite. [On Rendaku/Fortition in Loanwords]. Report of the Special Research Project for the Typological Investigation of Languages and Cultures of the East and West 1, 375-385. Tsukuba, Japan: Tsukuba University.

Tateishi, Koichi. 2003. Phonological Pattern and Lexical Strata. Proceedings of the Seventeenth International Congress of Linguistics (CD-ROM). Prague: Matfyz Press.

Tranel, Bernard. 1998. Suppletion and OT: On the Issue of Syntax/Phonology Interaction. Proceedings of the West Coast Conference on Formal Linguistics 16:415-429.

Vance, Timothy. 1987. An Introduction to Japanese Phonology. New York: State University of New York Press.

Vance, Timothy. 1996. Sequential Voicing in Sino-Japanese. Journal of the Association of Teachers of Japanese 30:22-43.

Kazutaka Kurisu

Kobe College

Department of English

4-1 Okadayama, Nishinomiya

Hyogo, 662-8505 Japan

kurisu@mail.kobe-c.ac.jp 